\title{
A preliminary study of the transport of air from Africa and Australia to New Zealand
}

\author{
A.P. Sturman*, P. D. Tyson ${ }^{\dagger}$, and P. C. D'Abreton ${ }^{\dagger}$
}

Kinematic trajectory modelling is used in a prelımınary examınation of inter-regional transport of air within the Southern Hemisphere In particular, the westerly zonal transport of arr in the lower troposphere from southern Africa and Australia to New Zealand is determined for January and July, using both forward and backward trajectories originatıng or ending up in the $850-800 \mathrm{hPa}$ layer respectively Mean transport plumes are derived from swarms of individual trajectories, and the results show that in winter around $22 \%$ of air originatıng over the central interior of South Africa reaches the central Tasman Sea south of New Zealand In summer the amount is insignificant owing to seasonal changes in the position of major circulation features In contrast, both summer and winter low-level air transport from southeastern and southwestern Australia and adjacent oceans to New Zealand is substantial, with $83 \%$ of all low-level arr parcels from the Sydney area in summer passing over central New Zealand 5 days later In winter the transport plume passes over the northern part of the North Island within 3 days Back trajectories show that in some seasons two distinct paths are followed by air arriving at Christchurch and Auckland, from the west-northwest and southwest Analysis of the vertical structure of the transport plumes arriving in New Zealand shows that the westerly air reaching Auckland in the $850-800 \mathrm{hPa}$ layer does so in a subsiding airstream throughout the year, whereas that arriving in the same layer over Christchurch experiences only minor subsidence en route from Australia and the ocean to the south This descending motion is related to the dominance of anticyclonic circulation, particularly over the northern section of the New Zealand region

Keywords Trajectory analysıs atmospherıc cırculatıon, aır movement New Zealand, Africa, Australıa

\section{INTRODUCTION}

Kinematic trajectory modellıng has revealed the extent to which large-scale transport of aerosols and trace gases is taking place out of southern Africa and far across the Indian Ocean (Garstang et al 1996a, Tyson et al 1996a,b) Isentropic modellıng confirms the existence of large-scale transport plumes exitıng the subcontınent en route towards Australasia (Thompson 1996, Thompson et al 1996) Such inter-regional and hemispheric transport of greenhouse gases has obvious and immediate consequences for regional manifestatıons of global warmıng (IPCC 1990, 1992, 1996) Likewise, the effects of aerosols are of considerable local, regional and global significance (Charlson et al 1990, 1992, Penner et al 1994) General circulation models (GCMs) incorporatıng sulphate aerosols show how regional patterns of global warmıng are ameliorated by the transport of the aerosols (Mitchell et al 1995a,b, Mitchell \& Johns 1997) In order to assess inter-regional transfers of aerosols and trace gases, and provide a basis for validating the GCM simulations of aerosol- and trace gas-induced regional changes, independent studies of atmospheric transport are required

\footnotetext{
*Department of Geography, University of Canterbury, Christchurch, New Zealand

${ }^{+}$Climatology Research Group, Unıversity of the Witwatersrand, Johannesburg, Republic of South Africa
} 
This paper represents a preliminary attempt to assess the extent to which air originating over southern Africa and Australia in mid summer and mid winter is transported over New Zealand. Further work is underway to provide a more comprehensive climatology of such air movements. An understanding of such air transport will provide the basis for subsequent assessment of the transport of aerosols and trace gases in the transporting medium.

\section{DATA AND METHODOLOGY}

Comparisons of kinematic and isentropic trajectory analysis have been undertaken by a number of authors (Pickering et al. 1994; D'Abreton 1996; Fuelberg et al. 1996). In the southern African region the kinematic approach has proved particularly useful (Garstang \& Tyson 1996; Garstang et al. 1996a,b, 1997; Tyson et al. 1996a,b,c,d; D'Abreton \& Tyson 1996) and has been accepted as the preferred method for this analysis. The D'Abreton model has therefore been used in this study, as described in detail in D'Abreton (1996).

European Centre for Medium Range Weather Forecasting (ECMWF) operational analyses of the 6-hourly, three-dimensional wind field at the $1000,900,850,800,700$ and $500 \mathrm{hPa}$ geopotential height levels provide the basis for deriving air transport fields from both forward and back trajectories of daily 1200 UTC air parcels originating from localities in South Africa, Australia and New Zealand. The method is based on the principle of Lagrangian advection, with the $u, v$ and $w$ wind components at given time, atmospheric layer and grid point used to compute a new downstream (upstream) location of an air parcel at a later (earlier) time. This procedure is then repeated to produce a forward or backward trajectory over several days. Given the stability discontinuity that occurs at about $500 \mathrm{hPa}$ on most days over southern Africa and adjacent oceans (Garstang et al. 1996a; Cosijn \& Tyson 1996), no analyses were performed above that level. Vertical velocities are determined from adiabatic non-linear mode initialisation, which permits the diabatic as well as the adiabatic processes which influence vertical motion to be considered. The ECMWF data set is based on a stateof-the-art model incorporating remotely sensed and drifting buoy data over data-sparse regions. The results that have been obtained are as good as the spatial and temporal time scales allow. However, it has been shown that the data are of high quality for this kind of trajectory analysis (Pickering et al. 1994). Data for January 1981 and 1989 and July 1980 and 1989 have been used and easterly and westerly components of zonal air transport have been determined. Fields defined by superimposing individual forward and back trajectories show clearly how trajectories from Africa and Australia might reach New Zealand (Fig. 1).

As pointed out by Pickering et al. (1996) and Garstang \& Tyson (1996), such swarms of individual trajectories require organising before they are useful. In this paper the method advocated by Tyson et al. (1996a) for determining mean transport plumes will be used. This consists of following individual trajectories through vertical longitudinal and latitudinal planes at specified time intervals. The heights, latitudes and longitudes of trajectory passages through successive planes are recorded in both eastward and westward directions. Penetrations of the planes are recorded as direct when arriving directly from the source and as recirculated when returning indirectly in the opposite direction to the initial motion from the source. By recording direct and indirect penetrations of successive planes it is possible to develop a clear depiction of direct and recirculated transport of air over a region. In this paper, only trajectories originating within the integrated near-surface $850-800 \mathrm{hPa}$ layer will be considered.

\section{Atmospheric circulation of the region between Africa and Australasia}

The mean sea level pressure field shows that atmospheric circulation in the southern Indian Ocean differs from that over other oceanic areas because the large subtropical anticyclone migrates westwards from about $90^{\circ} \mathrm{E}$ to around $60^{\circ} \mathrm{E}$ between summer and winter as it strengthens (Sturman \& Tapper 1996). At the same time, a winter mean high pressure area develops over southern Australia. It also appears that over much of the area of interest the westerlies move northwards $5-10^{\circ}$ in winter (and strengthen) and southwards in summer (and weaken), although the westerly wind belt tends to show little seasonal movement south 
Forward from Johannesburg

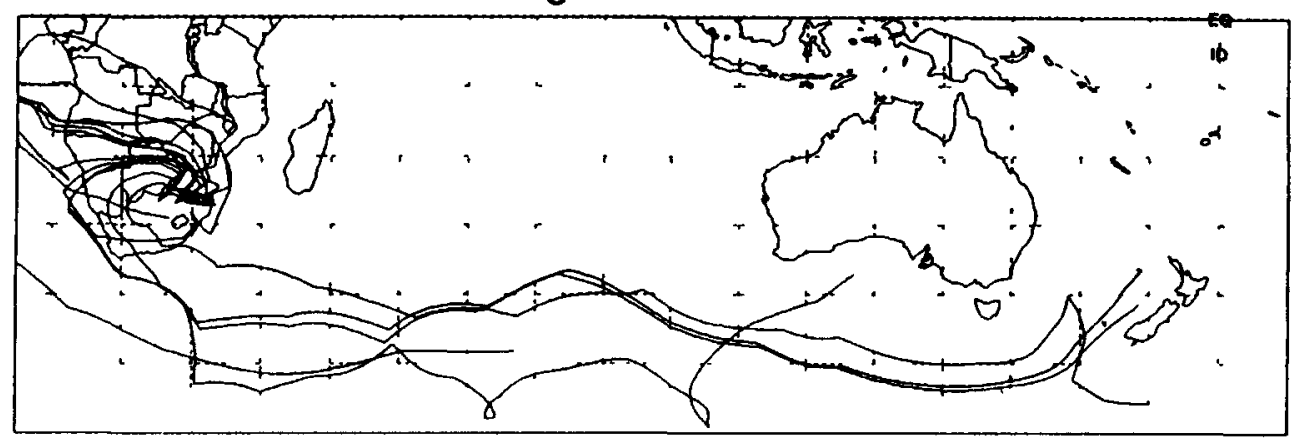

\section{Forward from Perth}

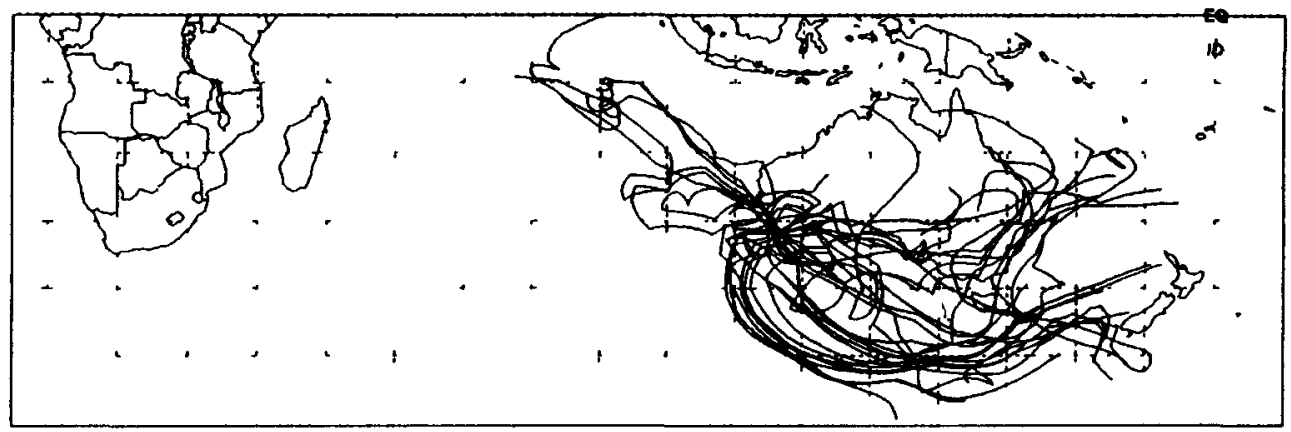

\section{Back from Mid Tasman Sea}

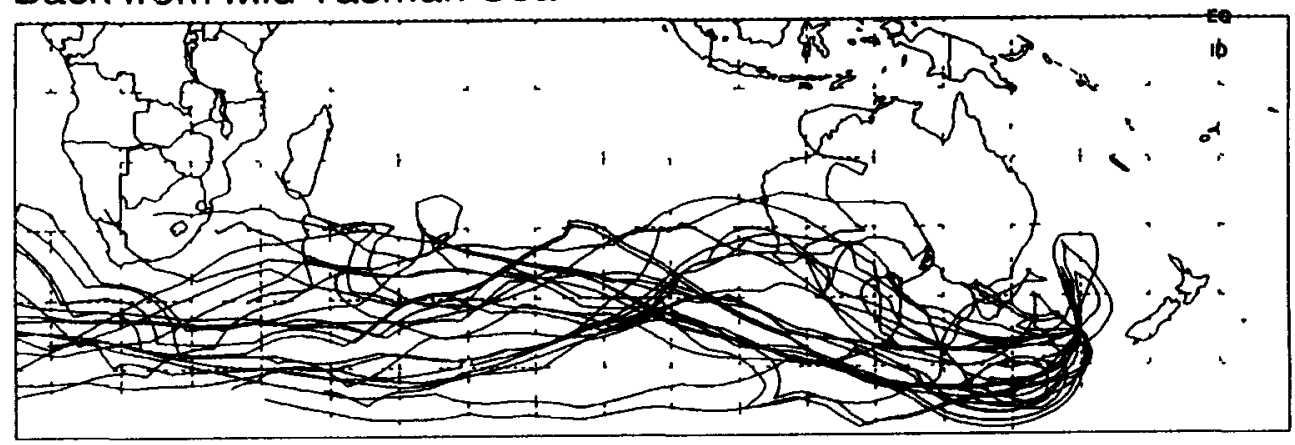

Fig 1 Examples of forward trajectory swarms from Johannesburg and Perth and a back trajectory swarm from the mid Tasman Sea

of New Zealand However, the mean pressure field does not give a true indication of the dayto-day variation of the near-surface mid-latitude circulation, which essentially controls air mass transport through this region This circulation is composed largely of eddies which tend to move eastwards under the control of the deep tropospheric westerlies, but which are also responsible for significant meridional air movement (Sturman \& Tapper 1996) The features responsible for the inter-regional transport of air between southern Africa and Australasia are therefore the individual anticyclonic and cyclonic systems that move through the area It is consequently important that a brief climatology of their occurrence be provided

Study of anticyclone occurrence in the Southern Hemisphere shows that in winter three preferred locations for anticyclones occur between South Africa and New Zealand These are 
around $90^{\circ} \mathrm{E}$ over the southern Indian Ocean, in the Australian Bight and over the northern Tasman Sea (Sinclair 1996). In summer the major location of anticyclones over the Indian Ocean moves laterally $30^{\circ}$ towards southern Africa, but shows very little meridional movement. However, over Australasia there is a significant $5-10^{\circ}$ northward shift in anticyclone location, while the two winter locations merge to create one region over southern and southeastern Australia, and there is a marked reduction in anticyclones over the northern Tasman Sea (Sinclair 1996). The most intense anticyclones occur in an area centred on $40^{\circ} \mathrm{S}$ and $60^{\circ} \mathrm{E}$ over the southern Indian Ocean, in the Tasman Sea and immediately to the east of New Zealand. In terms of their life cycle they tend to form over the southern tip of South Africa, over the southeast and southwest coasts of Australia and to the east of New Zealand. They intensify as they move over the southwestern Indian Ocean and the ocean south of Australia, and decay over the southeastern Indian Ocean, to the east of the Australian Bight and over the northern Tasman Sea. It therefore seems that anticyclones originating near South Africa tend to travel much faster and further across the southern Indian Ocean between formation and decay than those forming over and to the south of Australia. It is not surprising, then, that in comparison to the South Pacific, the southern Indian Ocean is relatively free of blocking (Sinclair 1996). This will be an important factor in the movement of air between Africa and Australasia. However, to the east and southeast of New Zealand is a prime area for anticyclonic blocking in the Southern Hemisphere (Sturman \& Tapper 1996), such that this process is likely to become significant as trajectories move towards and across the Tasman Sea.

In summer, cyclonic weather systems tend to pass well to the south of the area, with most centres around $60^{\circ} \mathrm{S}$ in the circumpolar trough (Sinclair 1995). In winter, regions with a high frequency of cyclonic systems move northwards, particularly to the south of Australia and the southeastern Indian Ocean, and a region of high frequency tends to straddle New Zealand. The area south and southeast of Australia experiences the highest track density of cyclonic systems for the Southern Hemisphere (Sinclair 1995). It is also relevant that the speed of movement of cyclonic systems through this region is at a maximum. The New Zealand region tends to experience an increased number of secondary depressions which form in the Tasman Sea during winter (Sturman \& Tapper 1996). Cyclogenesis occurs across a broad section of the southern part of the region in both seasons, with an increase in frequency during winter, while a particularly marked increase has been noted in the Tasman Sea off the coast of southeastern Australia (Sinclair 1995). The former cyclogenetic region is closely related to strong gradients in sea surface temperature, while the latter appears to be related to continental effects of Australia, the winter subtropical jet stream which has an exit region in this area, and a more localised sea surface temperature gradient off the southeast coast (Sturman \& Tapper 1996). These cyclonic systems reach maturity and decay either in the circumpolar trough or (in winter) in a region that extends northwards to about $40^{\circ} \mathrm{S}$ between $40^{\circ} \mathrm{E}$ and $140^{\circ} \mathrm{E}$ (Sinclair 1995). As with the anticyclones, seasonal changes in the distribution and movement of cyclonic systems in the region between Africa and Australasia play an important role in the transport of air across this sector of the Southern Hemisphere.

\section{Transport from Africa}

During winter (in July) the circumpolar vortex of the westerlies reaches its maximum equatorward extent. At this time of year, near-surface forward trajectories initiated from Johannesburg, in the industrial heartland of the Pretoria-Witwatersrand-Vereeniging region of South Africa, indicate a clear air transport plume streaming over the Indian Ocean (Fig. 2, upper). The $5 \%$ contour is the plume boundary within which $95 \%$ of all air parcel trajectories occur. At $40^{\circ} \mathrm{E}, 84 \%$ of air parcels cross the meridian after a mean transport time of 8 days and at a geopotential height between 875 and $760 \mathrm{hPa}$. One hundred degrees of longitude further east, the maximum frequency transport pathway is at about $50^{\circ} \mathrm{S}$. In this area, $30 \%$ of air parcels from southern Africa pass south of Australia after 16 days on average, and at a mean geopotential height of $550 \mathrm{hPa}$. During summer in January the westerlies retreat polewards. None the less, the plume-like structure of the region of transport is still evident, 

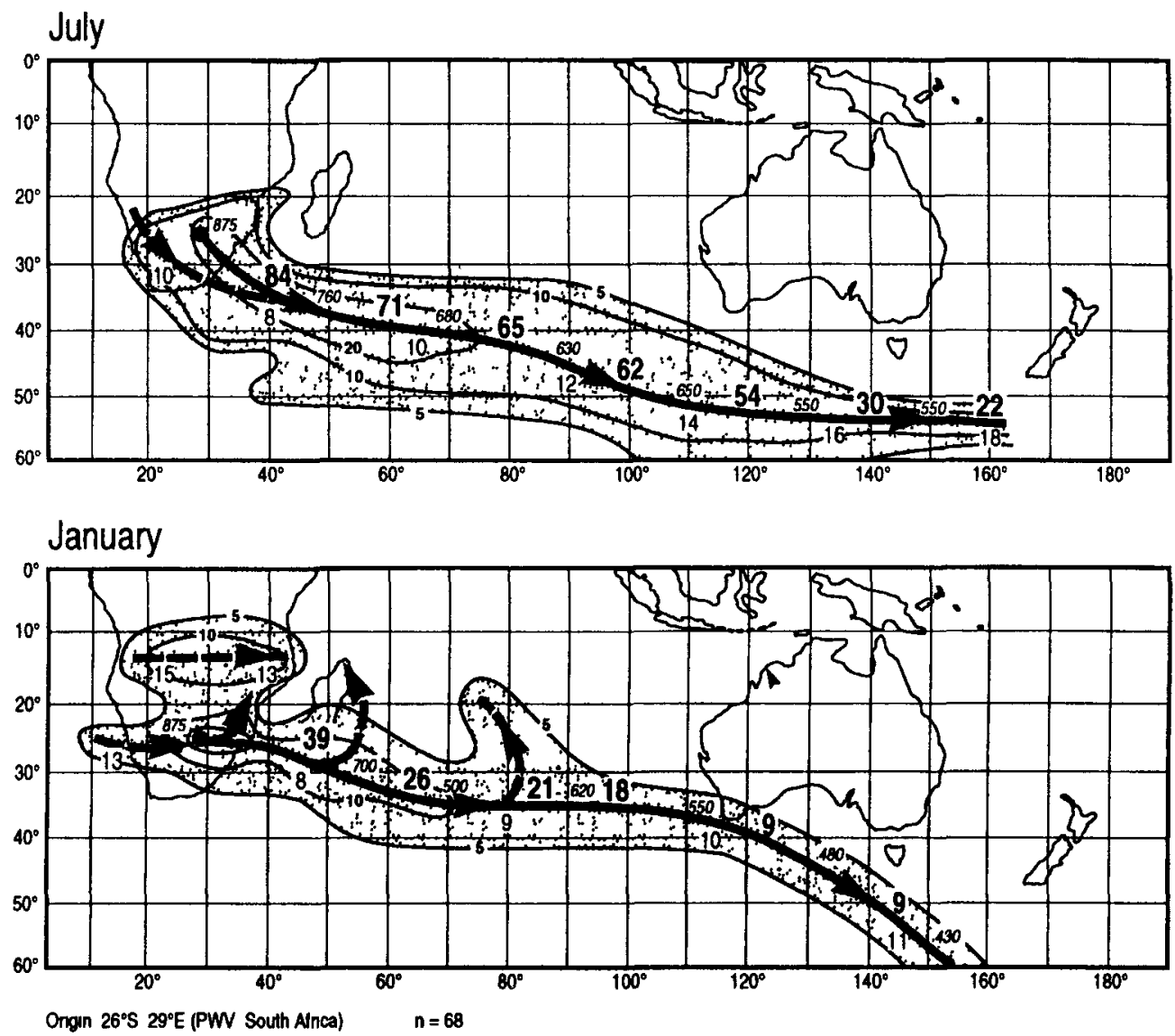

Fig. 2 Vertically integrated $850-800 \mathrm{hPa}$ westerly-component, zonal transport plumes for January and July, based on analysis of 68 forward trajectories from Johannesburg Contours give the percentage of air parcels originating at 850 and $800 \mathrm{hPa}$ Heavy solid lines indicate maximum frequency pathways, solid lines denote direct transport, broken lines indicate recirculated transport Along maximum frequency pathways bold numbers denote total percentage plume transport across the meridian, italic numbers indicate geopotential heights and normal arabic numbers transport tıme in days

but much less air is transported eastwards and far more tends to be recirculated back towards Africa (Fig 2, lower)

An alternative way of examıning the transport of air towards New Zealand from the west is to consider back trajectories from the region (Fig 3) In July, 74\% of air parcels in the 850$800 \mathrm{hPa}$ layer reach the central Tasman Sea, in roughly the middle of the 1996 Southern Hemisphere Marıne Aerosol Charactensation Experıment (ACE-1) field experımental area (ACE-1, 1995), after onginating 6 days earlier at $650 \mathrm{hPa}$ Fifty per cent onginate at $50^{\circ} \mathrm{E}$, south of Madagascar, at around $650 \mathrm{hPa}$ about 14 days before reaching the Tasman Sea Two distinctive tributary transport pathways are evident over Australia

The summer situation ( $\mathrm{F}_{1 \mathrm{~g}}$ 3, lower) shows recirculation occurring south of Australia (the figure of $106 \%$ indicates individual trajectories of air parcels crossing $140^{\circ} \mathrm{E}$ more than once) Less air from the African sector reaches the central Tasman Sea area in summer

\section{Transport from localities in Australia}

Two localities of origin, Perth and Sydney, will be used to illustrate air transport patterns In 

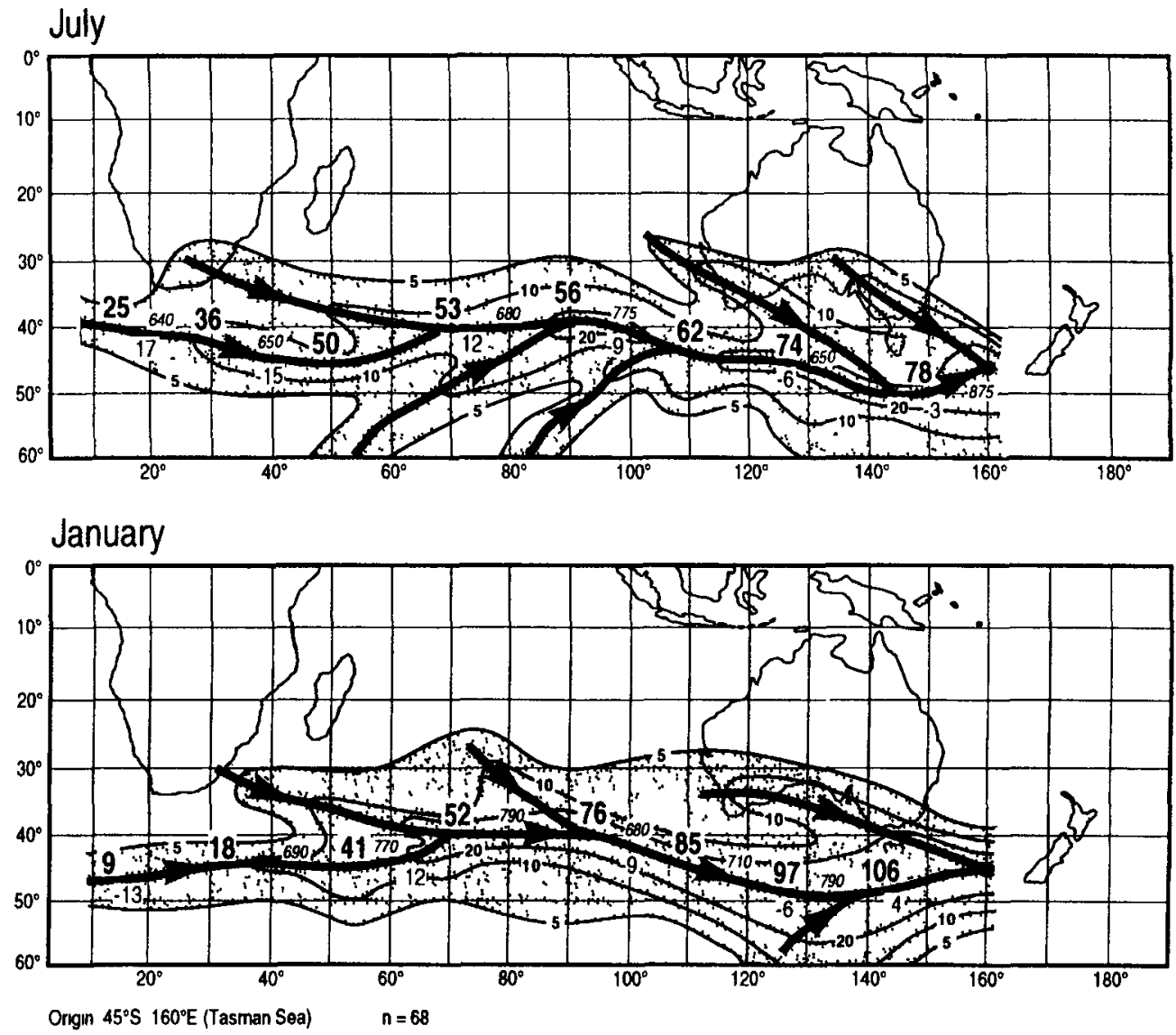

Fig. 3 Vertically integrated $850-800 \mathrm{hPa}$ westerly-component, zonal transport plumes for January and July, based on analysis of 68 back trajectories from $45^{\circ} \mathrm{S}, 160^{\circ} \mathrm{E}$ in the central Tasman Sea Labelling as in Fig 2

summer, the easterly component of transport from the Perth area of the western region of Australia is made up of two transport streams ( $F_{1} g$ 4) The first constitutes direct transport into the tropics to the north-west, the second consists of recirculated air moving back to the region from the north-east. The westerly component illustrates the extent to which the lowlevel air transported into the tropics itself recirculates back towards the point of ongin The stream of air transported directly to the south-east from Perth has little effect on New Zealand, as it passes well to the south

In winter, transport to the tropics in easterly-component flow from the Perth region is evident The main contrast between summer and winter conditions is the single major westerly transport plume in the latter season The westerly winter transport plume bifurcates, the pathway of greater frequency being to the south and towards New Zealand. More than a third of all air parcels initially moving eastwards from Perth arrive off the west coast of New Zealand within a week

Summer easterly air transport from Sydney shows no recirculation from the east $\left(\mathrm{F}_{1} \mathrm{~g} 5\right)$ Westerly transport, however, indicates that at $140^{\circ} \mathrm{E} 21 \%$ of the air parcels that originally moved westwards away from Sydney in the $850-800 \mathrm{hPa}$ layer return on average 7 days later from the west In the direct transport plume moving eastwards, $83 \%$ of all low-level air parcels from the Sydney region pass over New Zealand 5 days later. 


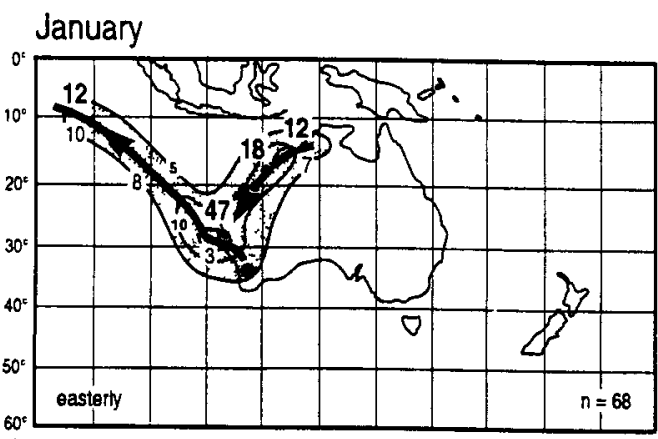

July
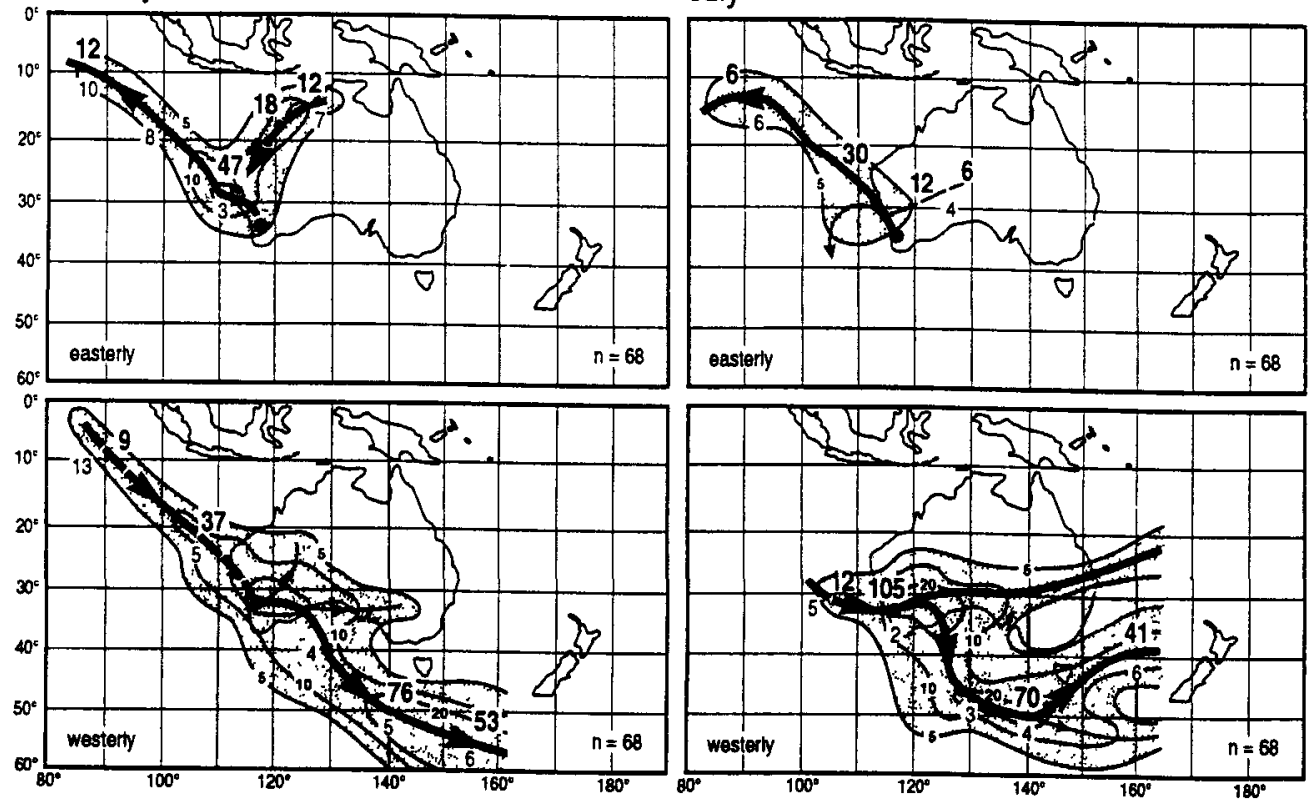

Fig. 4 Vertically integrated $850-800 \mathrm{hPa}$ westerly-component, zonal transport plumes for January and July, based on analysıs of 68 forward trajectories from Perth. Labelling as in Fig. 2.

The winter pattern shows that little direct transport occurs to the west from the Sydney area. The major transport plume is westerly, with the maximum frequency pathway passing north of the North Island, such that $90 \%$ of all air parcels in the integrated $850-800 \mathrm{hPa}$ layer reach $170^{\circ} \mathrm{E}$ in 3 days on average.

An alternative way of assessing transport into the New Zealand sector of the Southern Hemisphere is to consider specific receptor areas and then identify source areas of air by means of back trajectory analysis.

\section{Back trajectories from New Zealand}

Only low-level, $850-800 \mathrm{hPa}$ westerly transport into New Zealand will be considered. The two receptor areas to be examined are around Auckland and Christchurch. Summer westerly transport of air to the Auckland area consists of two streams, one passing over Australia and the other to the south of the continent (Fig. 6, upper left). A third of all westerly air parcels reaching Auckland originate south of Australia at $120^{\circ} \mathrm{E}$ a week earlier, with a significant preference for a southwesterly path. In winter, the transport pattern is more complicated and the source areas are somewhat more varied (Fig. 6, upper right).

Fifty-six percent of all $850-800 \mathrm{hPa}$ air parcels reaching Christchurch in summer cross $100^{\circ} \mathrm{E} 9$ days earlier, although the Southern Ocean is also a significant source (Fig. 6, lower left $)$. In winter, two westerly airstreams transport air to the area of the city, with slightly more air appearing to be transported in the more southerly of the two streams (Fig. 6, lower right). The two transport branches shown in Figure 6 may be related to the split-jet upper tropospheric structure which is a distinctive climatological feature of this area. Further work would be required to ascertain this.

The transport plumes arriving at the two localities in New Zealand are significantly different in vertical structure (Fig 7). In both summer and winter, the maximum frequency pathway of air transported over Auckland in the layer from 850 to $800 \mathrm{hPa}$ indicates a subsiding airstream descending from about the $650-700 \mathrm{hPa}$ level at $110^{\circ} \mathrm{E}$ to the west of 


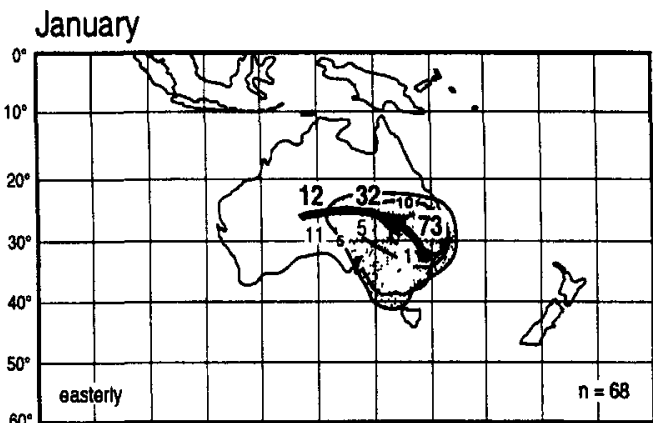

July
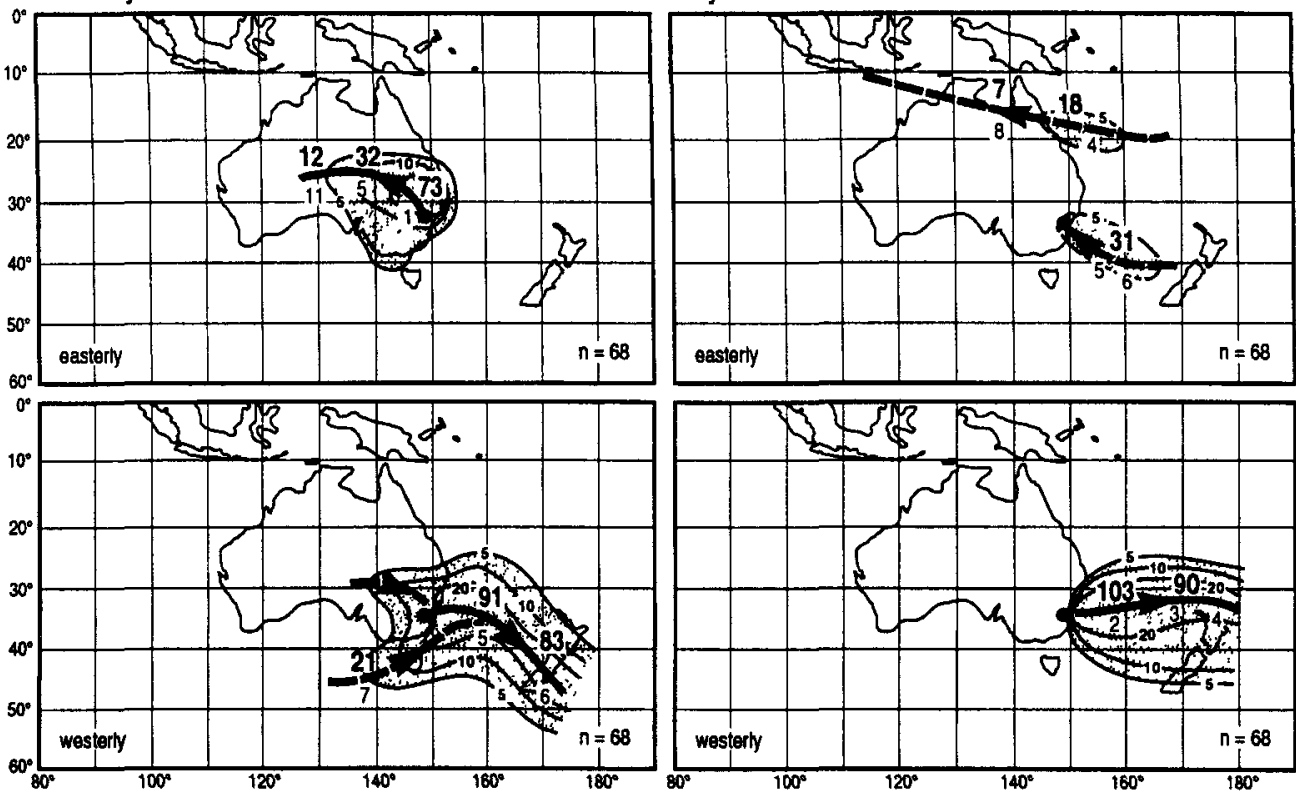

Fig. 5 Vertically integrated $850-800 \mathrm{hPa}$ westerly-component, zonal transport plumes for January and July, based on analysis of 68 forward trajectories from Sydney. Labelling as in Fig. 2.

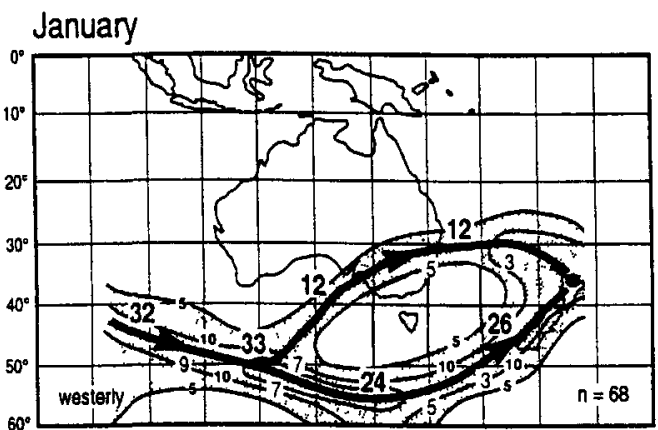

July
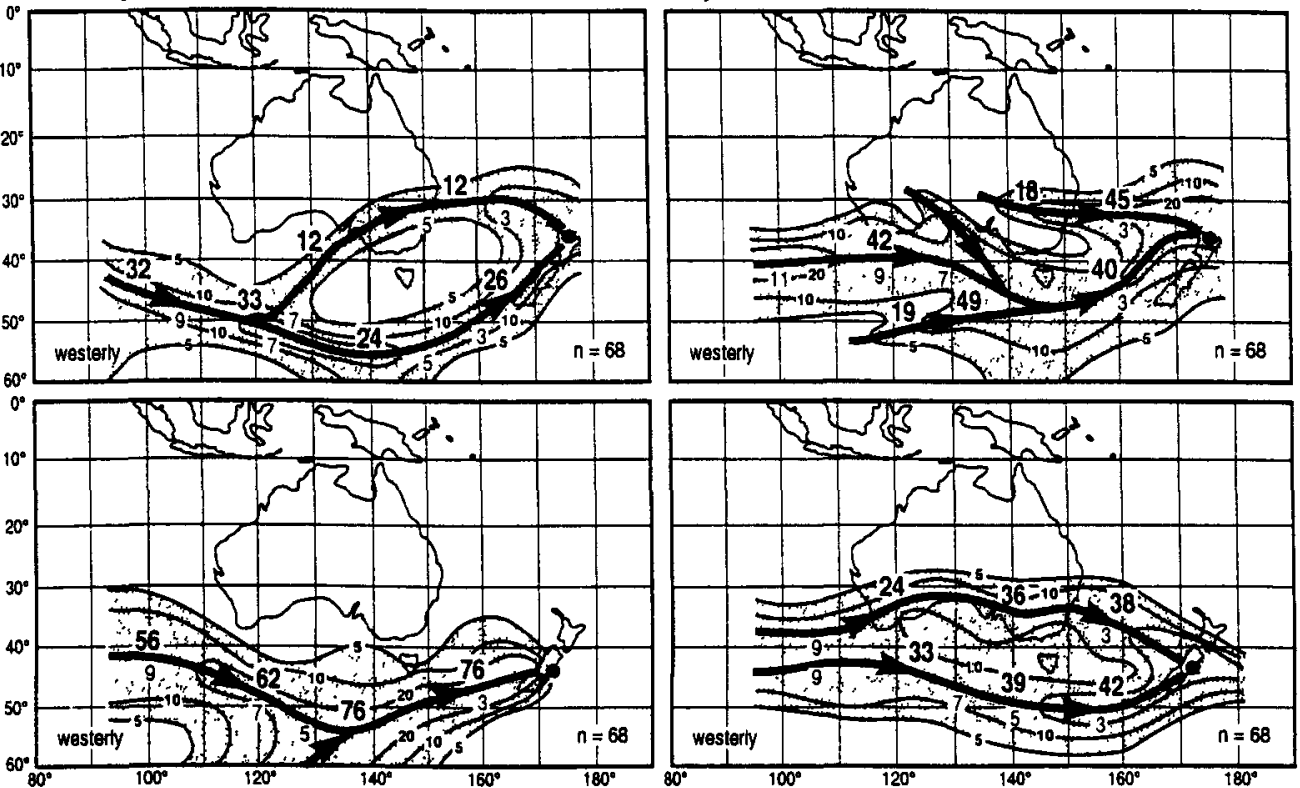

Fig. 6 Vertically integrated $850-800 \mathrm{hPa}$ westerly-component, zonal transport plumes in the horizontal for January and July, based on the analysis of 68 back trajectories from Auckland and Christchurch. Labelling as in Fig. 2. 

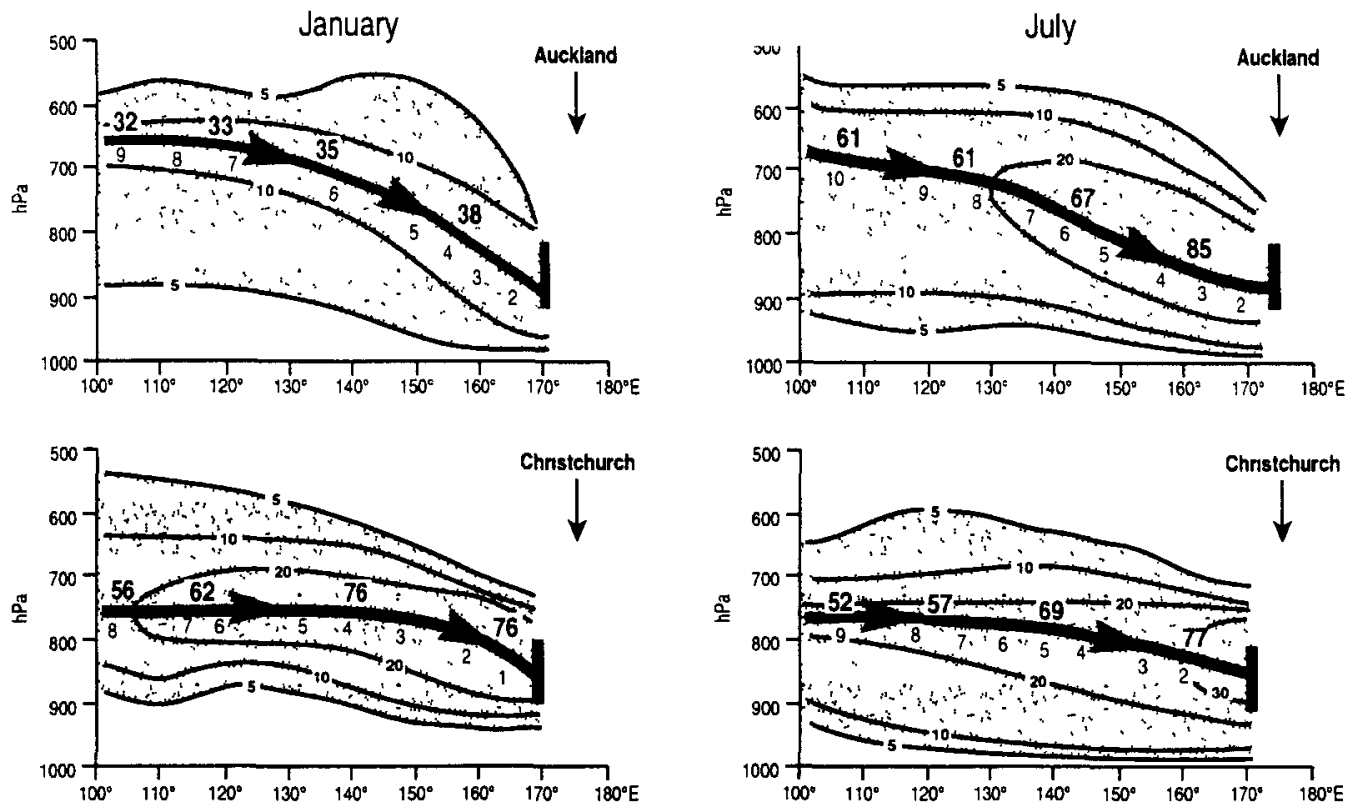

Fig. 7 Vertically-integrated $850-800 \mathrm{hPa}$ westerly-component, zonal transport plumes in the vertical for January and July based on the analysis of 68 back trajectories from Auckland and Christchurch. Labelling is as in Fig. 2.

western Australia. By contrast, the maximum frequency stream of air parcels reaching Christchurch in the same layer from the same longitude subsides at a much slower rate from around 750 to $800-850 \mathrm{hPa}$. Notably, in the summer and winter months studied, no mean ascent could be detected in the westerly flow over the South Island of New Zealand. The occurrence of sub-tropical anticylones over the northern Tasman Sea, as described earlier, appears to result in a greater amount of descent of air over the Auckland region than over Christchurch. The lack of a clear seasonal change in the nature of this descending motion needs further analysis using a larger data set. However, analysis of a catalogue of circulation types for the South Island of New Zealand, extended from the work of Sturman et al. (1984), shows that all four months are typical in respect of the frequency of anticyclones observed.

\section{DISCUSSION}

The transport patterns that have been established are preliminary, and must remain so until a larger data set can be analysed. The predominant trajectory paths for air between Australia and New Zealand compare well in form with those derived for westerly transport of air from southern Africa, but differ considerably in detail.

In this paper the transport of air-the carrier of trace gases and aerosols-has been discussed, and not the transport of the gases and particulate materials contained in the air. The mass fluxes of the transported products of anthropogenic urban and industrial, biomass burning and biogenic processes depend not only on the transport pathways of the air carrier but also on chemical reactions and wet and dry deposition that take place within the transport plume. The largest reduction in the transported load takes place near sources of emission. Nonetheless, material may be transported vast distances with long residence times.

Global mean residence times for aerosols are 2-7 days in the lower troposphere, 1-2 weeks in the upper troposphere and 3 weeks to 1 month at tropopause level (Pruppacher \& Klett 1980). In mid-latitude winters, when precipitation is common, the time taken to remove anthropogenic sulphate from the atmosphere is 4-5 days for North America and Europe 
(Benkovitz et al. 1994). For northern mid-latitudes, winter zonal mean aerosol turnover time is typically 4-6 days, whereas in the drier summers it is 6-15 days (Balkanski et al. 1993). Residence times of 5-10 days have been inferred from measurements of nuclear bomb-test radioactive species (Junge 1963; Chamberlain 1991) and 7-9 days from radio nuclides after the Chernobyl accident (Cambray et al. 1987). Particulate matter transported into, or formed in, the upper troposphere typically has lifetimes of weeks to months (Balkanski et al. 1993).

It has been shown that Saharan dust is transported in 4-11 days to the Caribbean and South America from northern Africa, distances of the order of $5000 \mathrm{~km}$ (Carlson \& Prospero 1972; Talbot et al. 1986; D'Almeida 1987; Talbot et al. 1996; Swap et al. 1993). Transport out of southern Africa occurs on similar time scales. Nitrogen isotope and elemental analyses show that biomass combustion products and soil dust constituents reached Ascension Island in the central South Atlantic Ocean, $4000 \mathrm{~km}$ from northern Namibia, in about 7 days (Swap et al. 1996; Swap 1996).

Likewise, transport of continentally-derived material from Africa over the Indian Ocean has been established. Moody et al. (1991) demonstrate from Global Chemistry Project analyses of rainfall samples collected over the period 1980-87 on Amsterdam Island, approximately midway between South Africa and Australia at about $38^{\circ} \mathrm{S}$ by $78^{\circ} \mathrm{E}$, that radon, non-sea salt sulphates and nitrates may be transported to the island from southern Africa and Madagascar - a distance exceeding $5000 \mathrm{~km}$ - in as little as 3 days on occasions. Garstang et al. (1996a) and Tyson et al. (1996a) show that with anticyclonic systems prevailing over South Africa, the average time of transport is 6.2 days to $70^{\circ} \mathrm{E}$. Tropospheric ozone plumes have likewise been observed to extend far over the Indian Ocean from southern Africa in spring (Fishman 1991; Fishman et al. 1991). It is suspected that emissions from biomass combustion over southern Africa cross the entire Indian Ocean, with pyrolized products being seen as far east as Tasmania in Australia (Bigg \& Turvey 1978; Heintzenberg $\&$ Bigg 1990). On occasions, dust plumes have been traced from southern Africa right across the ocean to Australia (Herman et al. 1997)

General circulation model (GCM) transport modelling of carbon dioxide tracer distributions from prescribed sources due to fossil fuel combustion and cement production and the seasonal fluxes associated with terrestrial biota, shows plumes extending eastwards from southern Africa (Rayner \& Law 1995). Some models show these plumes crossing only part of the Indian Ocean (the Colorado State University (CSU), Goddard Institute for Space Sciences (GISS) and Max Planck Institute (MPI) TM2 models), others show them reaching Australia (Australian Commonwealth Scientific and Industrial Research (CSIRO9), Geophysical Fluid Dynamics Laboratory (GFDL) National Center for Atmospheric Research (NCAR) models). The modelled carbon dioxide plumes indicate clearly the influence of continentally-derived air from Africa on the surrounding region of the Southern Hemisphere, and illustrate the effect of large-scale inter-regional transfer of trace gases.

Wind transport of insects, dust and other solid particles from Australia to New Zealand is a well established phenomenon (Collyer et al. 1984; Early et al. 1995), and Glasby (1971) has reviewed aeolian transport of dust across the Tasman Sea. Following an unusually dry winter in Australia, 'red rain' was observed in New Zealand in 1902 (Marshall 1903). In 1928 major dust storms in Australia were responsible for widespread dust falls in New Zealand (Marshall \& Kidson 1930), and further dust fell in 1929 (Kidson 1930). In 1966 red snow was reported in both the North Island and South Island (Windom 1969). Using mineralogical analysis, Collyer et al. (1984) demonstrated that kaolin in rainfall measured at Hokitika could only have been derived from Australia. Trajectory analyses confirmed the source and showed that the material had been transported from the east coast of Australia to the west coast of New Zealand in 1.5 days in a strong depression over the south Tasman Sea.

Australian pollens and various organisms are transported regularly to New Zealand by wind (Early et al. 1995). Reviews of the phenomenon are available (Tomlinson 1973; Fox 1978; Close et al. 1978; Gibbs 1980). Notable invasions of moths and butterflies occurred in 1956 (Ramsay \& Ordish 1966), 1971 (Ramsay 1971) and 1995 (Early et al. 1995). In the last- 
mentioned example, the trans-Tasman passage time from $24-32^{\circ} \mathrm{S}$ on the Australian east coast was about 25 days.

In making a first estimate of the possible effects of Australian industrial sulphur dioxide emissions on the acidity of New Zealand's rainfall, Holden \& Clarkson (1986) showed that on consecutive days from June to September 1983 about $30 \%$ of all air trajectories arriving in the north of New Zealand had originated over south-eastern Australia 3.3 days earlier.

\section{CONCLUSIONS}

Furst estimates of mean transport of air from southern Africa and parts of Australia to New Zealand have been provided. The possibility of inter-regional transfer between Africa and New Zealand exists, but the likelihood of large-scale transport of aerosols or trace gases between the two localities is not high. In contrast, a considerable potential for substantial atmospheric transport of suspended material in air from Australia to New Zealand definitely exists. On average it appears that air from the west coast of Australia reaches New Zealand withın a week in both summer and winter, and that from the east coast in about 4 days. Before the mass fluxes of aerosols and trace gases in the transporting airstreams can be established, it is necessary to undertake detailed transport studies by circulation type and season for the region, using a climatologically significant data set for a number of years. It will also be necessary to establish what if any El Niño-Southern Oscillatıon (ENSO) related variability might result in persistent and coherent changes in transport patterns in the New Zealand region. This research is underway and will be presented in subsequent papers.

Kinematıc trajectory modelling has been established as a useful means of determining regional and larger-scale transport of air. Provided that background concentrations of aerosols and trace gases and the rates of chemical conversion and wet and dry deposition are known, local and regional mass fluxes may be estımated. From these, the implications for regional and global clımatıc change may be investıgated.

\section{ACKNOWLEDGMENTS}

The authors wish to thank Philip Stıckler, Michelle Rogan and Wendy Job for preparıng the figures The research was funded by the Foundation for Research Development, the University of the Witwatersrand and the University of Canterbury, and was prepared for publication while one of the authors (Peter Tyson) was Erskıne Visitıng Fellow at the University of Canterbury The work is a contribution to the IGBP/WCRP/IHDP START programme for regional global change research

\section{REFERENCES}

ACE-1 1995 Southern Hemısphere Marıne Aerosol Characterısatıon Experıment (ACE-1), Final Scrence and Implementation Plan T Bates, NOAA/PMEL, Seattle. $99 \mathrm{pp}$

Balkanskı, Y J, Jacob, D J, Gardıner, G M, Grausteın, W G., Turekıan, K K 1993. Transport and residence times of tropospheric aerosols inferred from a global three-dimensional simulation of 210 $\mathrm{Pb}$ Journal of geophysical research 98 20 573-20 586

Benkovitz, C M, Berkowitz, C M, Easter, R C, Nemesure, S, Wagenerand, R, Schwartz, S E, 1994 Sulfate over the North Atlantic and adjacent contınental regions. evaluation for October and November 1986 using a three-dimensional model driven by observation-derived meteorology Journal of geophysical research $9920725-20756$

Bigg, F K, Turvey, D E 1978 Sources of atmospherıc partıcles over Australia Atmospheric environment 12 1643-1655

Cambray, R S, Cawse, P A, Garland, J A, Gibson, J A B, Johnson P, Lewis, G N J, Newton, D, Salmon, L, Wade, B O 1987 Observations on radioactivity from the Chernobyl accident Nuclear energy $26 \quad 77-101$

Carlson, T N, Prospero, J M, 1972 The long-range movement of Saharan arr outbreaks over the northern equatorial Atlantic Journal of applied meteorology 11 283-297

Chamberlain, A C, 1991 Radioactive Aerosols Cambridge Unıversity Press, New York $255 \mathrm{pp}$

Charlson, R J, Langer, J, Rohde, H 1990 Sulfate aerosol and clımate Nature 326 655-661 
Charlson, R J, Schwartz, S E, Hales, J M, Cess, R D, Coakley, J A, Hansen, J E ; Hofmann, D J 1992 Climate forcing by anthropogenic aerosols Science $255 \quad 422-430$

Close, R C , Moar, N T, Tomlınson, A I , Lowe, A D 1978 Aerial dispersal of biological material from Australia to New Zealand International journal of biometeorology $22 \quad 1-19$

Collyer, F X, Barnes, B G, Churchman, G J, Clarkson, T S, Steiner, J T 1984 A trans-Tasman dust transport event Weather and climate $4 \quad 42-46$

Cosijn C, Tyson P D, 1996 Stable discontinuities in the atmosphere over South Africa South African journal of science 92 381-386

D'Abreton, P C 1996 Lagrangian kınematic and isentropic trajectory models for aerosol and trace gas transport studies in southern Africa South African journal of science 92 157-160

D'Abreton, P C, Tyson, P D , 1996 Three-dimensional kınematıc trajectory modellıng of water vapour transport over southern Africa Water SA 22 297-306

D'Almeida, G A 1987 Desert aerosol characteristics and effects on climate In M Leinen \& M Sarnthein (eds) Palaeoclimatology and Palaeometeorology Modern and Past Patterns of Global Atmospheric Transport Kluwer Academic Publishers, Dordrecht $909 \mathrm{pp}$

Early, J W, Parrish, G R, Ryan, P A 1995 An invasıon of Australıan blue moth and blue tiger butterflıes (Lepıdoptera Nymphalıdae) in New Zealand Records of the Auckland Institute and Museum 32 45-53

Fishman, J , 1991 Probing planetary pollution from space Environmental sctence and technology 25 $612-621$

Fishman, J , Fakhruzzaman, K, Cros, B, Mganga, D 1991 Identification of widespread pollution in the Southern Hemisphere deduced from satellite analyses Sctence 252 1693-1696

Fox, K J 1978 The transoceanic migration of Lepidoptera to New Zealand - a history and a hypothesis on colonisation New Zealand entomologist 6 368-380

Fuelberg, $\mathrm{H}$ E, Loring, R O, Watson, M V, Sinha, M C , Pıckering, K E, Thompson, A M, Sachse, G W, Blake, D R, Schoeberl, M R 1996 TRACE-A trajectory intercomparison Part 2 Isentropic and kınematic methods Journal of geophysical research 101 23927-23937

Garstang, M , Tyson, P D , 1996 Atmospheric circulation, vertical structure and transport In B Van Wilgen, M O Andraea, J Goldammer \& J A Lindesay (eds) Fire in Southern African Savannas Ecological and Atmospheric Perspectives Witwatersrand Unıversity Press, Johannesburg Pp 5788

Garstang, M , Tyson, P D , Swap, R , Edwards, M , Kållberg, P, Lindesay, J A 1996a Horizontal and vertical transport of air over southern Africa Journal of geophysical research 101 23721-23736

Garstang, M , Tyson, P D, Browell, E, Swap, R 1996b Large scale transports of biogenic and biomass burning products In J S Levine (ed) Biomass Burning and Global Change MIT Press, Cambridge, Massachusets Pp 389-395

Garstang, M, Tyson, P D, Cachier, H, Radke, L 1997 Atmospherıc transports of partıculate and gaseous products by fire In J Clark (ed) Sediment Records of Biomass Burning and Global Change Springer-Verlag, New York Pp 207-250

Gibbs, G W 1980 New Zealand Butterfles Identification and Natural History Collins, Auckland $207 \mathrm{pp}$

Glasby, G P 1971 The influence of aeolian transport on marine sedimentation in the southwest Pacific Journal of the Roval Society of New Zealand 1 285-300

Heintzenberg, J, Bigg, E K 1990 Tropospheric transport of trace substances in the Southern Hemisphere Tellus 42B 355-363

Herman, J R, Bhartia, P B, Torres, O, Hsu, C, Celarıer, E, 1997 Global distribution of UVabsorbing aerosols from Nimbus-7/TOMS data Journal of geophysical research $10216911-$ 16922

Holden, R, Clarkson, T S 1986 Acıd rain a New Zealand perspectıve Journal of the Roval Socıety of New Zealand 16 1-15

IPCC 1990 Climate Change, The IPCC Sctentific Assessment J T Jenkıns \& J J Ephraums (eds) Cambridge University Press, Cambridge $365 \mathrm{pp}$

IPCC 1992 Climate Change 1992 The Supplementary Report to the IPCC Sctenttfic Assessment J T Houghton, B A Callander \& S K Varney (eds) Cambridge Unıversity Press, Cambridge $200 \mathrm{pp}$

IPCC 1996 Climate Change 1995, The Science of Climate Change J T Houghton, L G Miera Filho, B A Callander, N Harns, A Kattenburg \& K Maskell (eds) Cambridge University Press, Cambridge $572 \mathrm{pp}$

Junge, C E 1963 Atr Chemistry and Radioactivity Academic Press, New York 382 pp 
Kidson, E 1930 Australıan origin of red rain in New Zealand Nature 125410

Marshall, P 1903 Dust storms in New Zealand Nature 68223

Marshall, P, Kidson, E 1930 The dust storm of October 1928 New Zealand journal of science and technology $10 \quad 291-299$

Mitchell, J F B, Johns, T C, 1997 On the modification of global warming by sulphate aerosols Journal of climate $10 \quad 245-267$

Mitchell, J F B, Johns, T C, Gregory, J M, Tett, S B F 1995a Clımate response to increasing levels of greenhouse gases and sulphate aerosols Nature 376 501-504

Mitchell, J F B , Dav1s, R A , Ingram, W J , Senior, C A 1995b On surface temperature, greenhouse gases and aerosols models and observations Journal of cllmate 8 2364-2386

Moody, J L, Pszenny, A A P, Grandy, A, Keene, W C, Galloway, J N, Polıan, G 1991 Precipitation composition and its variability in the southern Indian Ocean Amsterdam Island, 1980 1987 Journal of geophysical research 96 20,769-20,786

Penner, J E , Charlson, R J, Hales, J M , Lauleınen, N, Leifer, R, Novakov, T, Ogren, J , Radke, L F, Schwartz, S E, Travis, L 1994 Quantıfying and minımising uncertainty of clımate forcing by anthropogenic aerosols Bulletin of the American Meteorological Soctety 75 375-400

Pickering, K E , Thompson, A M , McNamara, D P, Schoeberl, M R 1994 An inter-comparison of isentropic trajectories over the south Atlantic Monthly weather review 122 864-879

Pickerıng, K E, Thompson, A M, McNamara, D P, Schoeberl, M R, Fuelberg, H E, Loring, R O, Watson, M V , Fakhruzzaman, K, Bachmeier, A S 1996 TRACE-A trajectory intercomparison Part 1 Effects of different input analyses Journal of geophysical research 101 23909-23925

Pruppacher, H R, Klett, J D 1980 Microphysics of clouds and precipitation D Reidel, Dordrecht $714 \mathrm{pp}$

Ramsay, G W 1971 The blue moon butterfly Hypolımnas bolina nerina in New Zealand during autumn, 1971 New Zealand entomologist 5 73-75

Ramsay, G W, Ordish, R G 1966 The Australian blue moon butterfly Hypolimnas bolina nerina (F) in New Zealand New Zealand journal of science 9 719-729

Rayner, P J, Law, R M 1995 A comparison of modelled responses to prescribed $\mathrm{CO}_{2}$ sources CSIRO Australian Division of Atmospheric Research Technical Paper No $3682 \mathrm{pp}$

Sinclair, M R 1995 A climatology of cyclogenesis for the Southern Hemisphere Monthly weather review 12316011619

Sinclair, M R 1996 A clımatology of antıcyclones and blockıng for the Southern Hemisphere Monthly weather review 124 245-263

Sturman, A P, Tapper, N J 1996 The weather and climate of Australla and New Zealand Oxford University Press, Melbourne $476 \mathrm{pp}$

Sturman, A P , Trewinnard, A , Gorman, P 1984 A study of atmospherıc circulation over the South Island of New Zealand (1961-1980) Weather and climate 4 53-62

Swap, R J 1996 Transport and impact of southern African aerosols Unpublished PhD dissertation, University of Virginia, Charlottesville $170 \mathrm{pp}$

Swap, R J, Garstang, M , Greco, S , Talbot, R W , Kăllberg, P 1993 Saharan dust in the Amazon Basin Tellus 44 133-149

Swap, R , Garstang, M , Macko, S A, Tyson, P D , Maenhaut, W , Artaxo, P , Kållberg, P , Talbot, R 1996 The long-range transport of southern African aerosols to the tropical south Atlantic Journal of geophvsical research I01 2377723791

Talbot, R W, Harriss, R C, Browell, E V, Gregory, G L, Sebacher, D I, Beck, S M 1986 Distribution and geochemistry of aerosols in the tropical North Atlantic troposphere relation to Saharan dust Journal of geophysical research 91 5153-5182

Talbot, R W, Bradshaw, J D, Sandholm, S, Smyth, S, Blake, D R, Blake, N, Sachse, G W, Collıns, J, Heıkes, B G, Anderson, B E, Gregory, G L, Singh, H B, Lefer, B L, Bachmeier, A S 1996 Chemical characteristics of continental outflow over the tropical South Atlantic Ocean from Brazil and Africa Journal of geophysical research 1012418724202

Thompson, A M 1996 Evaluation of biomass burning effects on ozone during SAFARI/TRACE-A examples from the process models $I n \mathrm{~J}$ S Levine (ed) Blomass Burning and Global Change MIT Press, Cambridge, Mass , pp 333-349

Thompson, A M, Zenker, T, Gregory, E , Bodeker, G, McNamara, D P 1996 Ozone over southern Africa patterns and influences In B Van Wilgen, $\mathrm{M} O$ Andraea, $\mathrm{J}$ Goldammer \& J A Lindesay (eds) Fire in Southern African Savannas Ecological and Atmospheric Perspectives Witwatersrand Unıversity Press, Johannesburg, pp 185-216 
Tomlinson, A.I. 1973: Meteorological aspects of trans-Tasman insect dispersal. New Zealand entomologist 5: 253-268.

Tyson, P. D.; Garstang, M.; Swap, R.; Kållberg, P.; Edwards, M. 1996a: An air transport climatology for subtropical southern Africa. International journal of climatology 16: 265-291.

Tyson, P. D.; Garstang, M.; Thompson, A. M.; D'Abreton, P. C.; Diab, R. D.; Browell, E.V. 1996b: Horizontal and vertical transport of ozone over south central southern Africa. Journal of geophysical research 102: $10623-10635$.

Tyson, P. D.; Garstang, M.; Swap, R. 1996c: Large-scale recirculation of air over southern Africa. Journal of applied meteorology 35: 2218-2236.

Tyson. P. D.; Garstang, M.; Swap, R.; Browell, E. V.; Diab, R. D.; Thompson, A. M. 1996d: Transport and vertical structure of ozone and aerosol distributions over southern Africa. In J. S. Levine (ed) Biomass Burning and Global Change. MIT Press, Cambridge, Mass., pp 403-421.

Windom, H. L. 1969: Atmospheric dust records in permanent snowfields: implications for marine sedimentation. Geological Society of America bulletin 80: 761-782. 